\title{
Effects of Emulsifier and Multi-enzyme in Different Energy Densitydiet on Growth Performance, Blood Profiles, and Relative Organ Weight in Broiler Chickens
}

\author{
Jin Ho Cho ${ }^{1}$, PingYo Zhao ${ }^{1} \&$ In Ho Kim ${ }^{1}$ \\ ${ }^{1}$ Department of Animal Resource \& Science, Dankook University, Anseodong, Cheonan, Choongnam 330-714 \\ South Korea \\ Correspondence: In Ho Kim, Department of Animal Resource \& Science, Dankook University No. 29 \\ Anseodong, Cheonan, Choognam, 330-714, South Korea. Tel: 82-41-550-3652. E-mail: inhokim@dankook.ac.kr
}

Received: June 13, 2012 Accepted: July 4, 2012 Online Published: August 31, 2012

doi:10.5539/jas.v4n10p161 URL: http://dx.doi.org/10.5539/jas.v4n10p161

\begin{abstract}
This study was conducted to determine the effects of emulsifierand multi-enzyme in different energy density diet on growth performance, blood profiles, and relative organ weight in broiler chickens. A total of five hundred and forty2-d-oldmale Ross broilers (BW of $42.4 \pm 1.3 \mathrm{~g}$ ) wereused in a 35-d experiment and randomly divided into 5 treatment groups: 1) NC [low energy diet, $3 \%$ tallow, $\mathrm{ME}=3000(1$ to $21 \mathrm{~d}$ ) and $3100 \mathrm{kcal} / \mathrm{kg}$ (22 to $35 \mathrm{~d})$ ], 2) $\mathrm{PC}$ [high energy diet, $5.5 \%$ soybean oil, $\mathrm{ME}=3150$ ( 1 to $21 \mathrm{~d}$ ) and $3250 \mathrm{kcal} / \mathrm{kg}(22$ to $35 \mathrm{~d})$ )], 3) P1 (NC+0.1\% multi-enzyme), 4) $\mathrm{P} 2$ ( $\mathrm{NC}+0.05 \%$ emulsifier), 5) $\mathrm{P} 3(\mathrm{NC}+0.1 \%$ multi-enzyme $+0.05 \%$ emulsifier). Multi-enzymecontained $\alpha$-galactosidase, galactomannase, xylanase, and $\beta$-glucanase. Emulsifier was a commercial product named Prosol ${ }^{\circledR}$ which wassodium stearoyl-2-lactylate.There were 9 replications per treatment with 12 birds per pen. From d 0 to 21, body weight gain (BWG) in PC and P1 treatments increased (P $<0.05)$ compared with NC treatment. From d 22 to 35, feed intake $(\mathrm{FI})$ was greater $(\mathrm{P}<0.05)$ in $\mathrm{P} 3$ treatment than PC treatment. On d 35, triglyceride concentration in PC, P1 and P3 treatments was greater $(\mathrm{P}<0.05)$ compared with $\mathrm{NC}$ treatment. No differences were observed on white blood cell (WBC), red blood cell (RBC) and glucose concentration. The relative weight of the spleen was significantly decreased $(\mathrm{P}<0.05)$ in $\mathrm{P} 3$ treatment compared with PC treatment. Furthermore, the relative weight of the bursa of Fabricius in $\mathrm{P} 3$ treatment was higher $(\mathrm{P}<0.05)$ than $\mathrm{PC}, \mathrm{P} 1$ and $\mathrm{P} 2$ treatments. In conclusion, the results of this study indicate that emulsifier andmulti-enzymein low-density diets can partially improve growth performance, triglyceride, and relative organ weight in broiler chickens, which can counterpart the negative effects caused by the decreased nutrient concentration.
\end{abstract}

Keywords: cholesterol, emulsifier, multi-enzyme, fatty acid profile, broilers

\section{Introduction}

Sodium stearoyl-2-lactylate (SSL) is the sodium salt of a long-chained carboxylic acid containing two ester linkages. It is applied as emulsifier (Gomez et al., 2004; Manohar et al., 1999), whipping agent (Kelly et al., 1999) and conditioning agent (Armero et al., 1998) in a wide variety of modern food technologies. Emulsification is required for micellar formation and absorption of fat, so exogenous emulsifiers may enhance fat utilization fed high-fat diet. Kussaibati et al. (1982) reported that bile salts supplementation in broiler chicken diets improves emulsion formation and fat digestibility. Emulsifier promotes the incorporation of fatty acids into micelles. Augur et al. (1947) and Polin (1980) reported that digestibility of fat increased when emulsifier was mixed with the fat before it was fed to rats and chicks, respectively. Research investigating the effect of emulsifiers on performance of broiler chickens is limited, so further researches need to be taken. Therefore, with the current high prices of feed ingredients, nutritional emulsifiers may help in reducing feed costs if beneficial effect was observed in broiler chickens.

The presence of galactomannan in the diet has been shown to diminish the growth of broilers (Ray et al. 1982). Use of exogenous enzymes may also provide opportunities to utilize $\alpha$-1, 6-galactosides and $\beta$-galactomannan as energy sources (Kim et al., 2003; Wang et al., 2009; Ao et al., 2011). Multi-enzyme contains $\alpha$-galactosidase, galactomannase, xylanse and $\beta$-glucanase. The $\alpha$-galactosides of sucrose can't be broken down in the small intestine of chickens or pigs due to the absence of endogenous $\alpha-(1,6)$-galactosidase (Gitzelmann et al., 1965). Exogenous $\alpha$-galactosidase enzymes supplementation for chickens has led to variable results (Ghazi et al., 1997; 
Ghazi et al., 2003; Graham et al., 2002; Knap et al., 1996; Kidd et al., 2001a,b). Waldroup et al. (2005) reported that in their previous study, they were unable to detect an improvement in the energy value of soybean meal as a result of addition of $\alpha$-galactosidase enzyme. Until now, the effect of multi-enzyme on growth performance in broiler chickens remains unclear.

The principal objective of this study was to evaluate effects of emulsifier and multi-enzyme on growth performance, blood profiles, and relative organ weight in broiler chickens.

\section{Materials and Methods}

All broilers used in this trial were handled in accordance with the guidelines set forth by the Animal Care and Use Committee of Dankook University.Sodium stearoyl-2-lactylate $\left(\operatorname{Prosol}^{\mathbb{}}{ }^{\text {}}\right.$ ) which was supplied by Il Shin WellsCompany (Seoul, South Korea).

\subsection{Enzyme Preparation}

Multi-enzyme preparation (Endopower ${ }^{\circledR}$, EasyBio System Incorporated, Seoul, South Korea) contains 7 unit/g $\alpha$-galactosidase activity, $22 \mathrm{unit} / \mathrm{g}$ galactomannanase activity, $300 \mathrm{unit} / \mathrm{g}$ xylanase activity and 220 unit $/ \mathrm{g} \beta$-glucanase activity. One unit of $\alpha$-galactosidase is defined as the amount of enzyme that liberates 0.1 $\mu \mathrm{mol}$ nitro phenol from $2 \mathrm{mmol}$ of $\mathrm{pNPG}$ (p-nitrophenyl-alpha-dgalactoside) per at $30^{\circ} \mathrm{C}$ and $\mathrm{pH} 4.0$. One unit of galactomannase is defined as the amount of enzyme that liberates $0.1 \mu \mathrm{mol}$ total reducing sugars $/ \mathrm{min}$ from $0.5 \%$ galactomannan per at $30^{\circ} \mathrm{C}$ and $\mathrm{pH} 4.0$. One unit of xylanase is defined as the amount of enzyme that liberates 1 $\mathrm{mg}$ total reducing sugar $/ 10 \mathrm{~min}$. from $0.5 \%$ xylan at $30^{\circ} \mathrm{C}$ and $\mathrm{pH} 4.0$. One unit of $\beta$-glucanase is defined as the amount of enzyme that liberates $1 \mathrm{mg}$ of total reducing sugar per $10 \mathrm{~min}$ from $0.4 \% \beta$-glucan at $30^{\circ} \mathrm{C}$ and $\mathrm{pH}$ 4.0.

\subsection{Experimental Design, Animals, and Housing}

A total of five hundred and forty2-d-old male Ross broiler chickens (BW of $42.4 \pm 1.3 \mathrm{~g}$ ) were used in a 35-d experiment. Broiler chickens were allotted into 5 treatments and there were 9 replications per treatment with 12 birds per pen.Dietary treatment groups include: 1) NC [low energy diet, $3 \%$ tallow, $\mathrm{ME}=3000$ (1 to $21 \mathrm{~d}$ ) and $3100 \mathrm{kcal} / \mathrm{kg}$ (22 to $35 \mathrm{~d}$ )], 2) PC [high energy diet, 5.5\% soybean oil, $\mathrm{ME}=3150$ (1 to $21 \mathrm{~d}$ ) and $3250 \mathrm{kcal} / \mathrm{kg}$ (22 to $35 \mathrm{~d})$ )], 3) P1 ( $\mathrm{NC}+0.1 \%$ multi-enzyme), 4) P2 ( $\mathrm{NC}+0.05 \%$ emulsifier), 5) P3 ( $\mathrm{NC}+0.1 \%$ multi-enzyme $+0.05 \%$ emulsifier). The basal diets were formulated to meet or exceed the NRC (1994) nutrient requirements. Broiler chickens were raised in a temperature-controlled room with stainless steel pens of identical size $(1.75 \times 1.55 \mathrm{~m})$. Room temperature began at $33^{\circ} \mathrm{C}$ from $\mathrm{d} 1$ to 3 and was reduced gradually to $24^{\circ} \mathrm{C}$ until the end of the experiment and the relative humidity was around $60 \%$.Broiler chickens received diet and water ad libitum. Each pen had a pan feeder with a $35-\mathrm{cm}$ diameter. Water was provided by evenly spaced nipple drinkers ( 5 nipples per pen) positioned along the side wall of the pen.

\subsection{Sampling and Measurements}

All diets were grounded through a 1-mm screen in a Wiley mill before analyzing for crude protein (CP), calcium (Ca), and phosphorus (P) (AOAC, 2003). N content in diets was determined by using a Kjeltec 2300 Analyzer (Foss Tecator AB, Hoeganaes, Sweden). Amino acids (excluding tryptophan) in diets were analyzed by dansylation (Beckman Intruments Inc., Fullerton, CA) and HPLC after acid hydrolysis for 24h in $6 \mathrm{M} \mathrm{HCl}$.

The broiler chickens were weighed by pen and feed intake (FI) was recorded on $\mathrm{d} 0,7,21$, and 35 to calculate body weight gain (BWG) and feed conversion ratio (FCR). At the end of the experiment, 45 broiler chickens were randomly selected from each treatment ( 5 birds per pen) and blood samples were collected from the wing vein into a sterile syringe and stored at $-4^{\circ} \mathrm{C}$. The white blood cell (WBC), red blood cell (RBC), and lymphocyte counts in the whole blood were then determined using an automatic blood analyzer (ADVIA 120, Bayer, Tarrytown, NY). Samples for serum analysis were then centrifuged at $3,000 \times \mathrm{g}$ for 15 minutes at $4^{\circ} \mathrm{C}$. The concentrations of glucose and triglyceride in the serum samples were analyzed with an automatic biochemical analyzer (RA-1000, Bayer Corp., Tarrytown, NY) using colorimetric methods.After blood collection, the same broiler chickens were weighed individually and slaughtered by cervical dislocation. The liver, spleen, bursa of Fabricius, breast meat, abdominal fat, and gizzard were then removed by trained personnel and weighed.To avoid variation in the cutting procedures, the same operator was employed. Organ weight was expressed as a percentage of BW.

\subsection{Statistical Analysis}

All experimental data was analyzed in accordance with the GLM Procedure (SAS, 1996). The pen was used as the experimental unit.Differences among treatment means were determined using the Duncan's multiple range test. A probability level of $\mathrm{P}<0.05$ was considered to be statistically significant. 


\section{Results}

\subsection{Growth Performance}

From $\mathrm{d} 0$ to 21, BWG of broiler chickens fed the $\mathrm{PC}$ and $\mathrm{P} 1$ diets increased $(\mathrm{P}<0.05)$ compared with broiler chickens fed the NC diet (Table 2). Feed intake (FI) and feed conversion ratio (FCR) of broiler chickens weren't affected by any treatment diets. From d 22 to 35 , FI was greater $(\mathrm{P}<0.05)$ in $\mathrm{P} 3$ treatment than $\mathrm{PC}$ treatment and there were no differences on BWGand FCR. During the overall experiment, no significant differences in BWG, FI, and FCR were observed among the dietary treatments.

\subsection{Blood Profiles}

On d35, triglyceride concentration of broiler chickenblood fed PC, P1 and P3 diets was greater $(\mathrm{P}<0.05)$ compared with $\mathrm{NC}$ diet (Table 3). In our study, there were no differences in WBC, RBC and glucose concentration in broiler chicken blood.

\subsection{Relative Organ Weight}

The relative weight of the spleen was significantly decreased $(\mathrm{P}<0.05)$ in $\mathrm{P} 3$ treatment compared with $\mathrm{PC}$ treatment (Table 3). Furthermore, the relative weight of the bursa of Fabricius in $\mathrm{P} 3$ treatment was higher $(\mathrm{P}<$ 0.05) than PC, P1 and P2 treatments. The relative weight of the liver, breast meat, abdominal fat and gizzard remained unaffected by any treatment diets.

Table 1. Compositions of basal broiler chicken diets (as-fed basis)

\begin{tabular}{|c|c|c|c|c|}
\hline \multirow[b]{2}{*}{ Item } & \multicolumn{2}{|c|}{ Starter $^{1}$} & \multicolumn{2}{|c|}{ Finisher $^{1}$} \\
\hline & $\mathrm{NC}$ & $\mathrm{PC}$ & $\mathrm{NC}$ & $\mathrm{PC}$ \\
\hline \multicolumn{5}{|l|}{ Ingredients $(\%)$} \\
\hline Corn & 49.92 & 55.30 & 58.87 & 67.33 \\
\hline Soybean meal (CP 48\%) & 30.25 & 28.25 & 24.61 & 20.61 \\
\hline Corn gluten meal (CP $60 \%)$ & 6.50 & 6.50 & 3.50 & 3.50 \\
\hline Rice rye & 6.00 & - & 6.00 & - \\
\hline Soybean oil & - & 5.50 & - & 4.50 \\
\hline Tallow & 3.00 & - & 3.00 & - \\
\hline Dicalcium phosphate & 2.46 & 2.46 & 2.29 & 2.29 \\
\hline Limestone & 0.89 & 0.89 & 0.75 & 0.75 \\
\hline Salt & 0.20 & 0.20 & 0.20 & 0.20 \\
\hline $\mathrm{DL}^{-}$-Methionine (98\%) & 0.17 & 0.29 & 0.17 & 0.21 \\
\hline L-Lysine-HCl (78\%) & 0.21 & 0.21 & 0.21 & 0.21 \\
\hline Vitamin premix ${ }^{2}$ & 0.20 & 0.20 & 0.20 & 0.20 \\
\hline Trace mineral premix ${ }^{3}$ & 0.20 & 0.20 & 0.20 & 0.20 \\
\hline \multicolumn{5}{|l|}{ Calculated composition, \% } \\
\hline $\mathrm{ME}, \mathrm{kcal} / \mathrm{kg}$ & 3100.00 & 3250.00 & 3025.00 & 3175.00 \\
\hline $\mathrm{CP}$ & 22.00 & 22.00 & 19.00 & 19.00 \\
\hline Lysine & 1.10 & 1.10 & 1.00 & 1.00 \\
\hline $\mathrm{Ca}$ & 1.00 & 1.00 & 0.90 & 0.90 \\
\hline Available P & 0.80 & 0.80 & 0.75 & 0.75 \\
\hline Met+Cys & 0.89 & 0.89 & 0.84 & 0.84 \\
\hline \multicolumn{5}{|l|}{ Analytical composition, \% } \\
\hline $\mathrm{CP}$ & 22.30 & 22.30 & 20.10 & 20.10 \\
\hline $\mathrm{Ca}$ & 1.00 & 1.00 & 0.91 & 0.91 \\
\hline Met + Cys & 0.88 & 0.88 & 0.85 & 0.85 \\
\hline Available P & 0.45 & 0.45 & 0.40 & 0.40 \\
\hline
\end{tabular}

${ }^{1}$ Starter diets, provided during week 0 to 3; grower diets, provided during week 4 to 5 .

${ }^{2}$ Provided per kg of diet: 15,000 IU of vitamin A, 3,750 IU of vitamin D3, $37.5 \mathrm{mg}$ of vitamin E, $2.55 \mathrm{mg}$ of vitamin $\mathrm{K} 3,3 \mathrm{mg}$ of thiamin, $7.5 \mathrm{mg}$ of riboflavin, $4.5 \mathrm{mg}$ of vitamin B6, $24 \mu \mathrm{g}$ of vitamin B12, $51 \mathrm{mg}$ of niacin, $1.5 \mathrm{mg}$ of folic acid, $0.2 \mathrm{mg}$ of biotin and $13.5 \mathrm{mg}$ of pantothenic acid.

${ }^{3}$ Provided per kg of diet: $37.5 \mathrm{mg} \mathrm{Zn}\left(\right.$ as $\left.\mathrm{ZnSO}_{4}\right), 37.5 \mathrm{mg}$ of $\mathrm{Mn}\left(\mathrm{MnO}_{2}\right), 37.5 \mathrm{mg}$ of $\mathrm{Fe}\left(\right.$ as $\left.\mathrm{FeSO}_{4} \cdot 7 \mathrm{H}_{2} \mathrm{O}\right), 3.75$ $\mathrm{mg}$ of $\mathrm{Cu}\left(\right.$ as $\left.\mathrm{CuSO}_{4} \cdot 5 \mathrm{H}_{2} \mathrm{O}\right), 0.83 \mathrm{mg}$ of I (as KI), and $0.23 \mathrm{mg}$ of $\mathrm{Se}\left(\right.$ as $\left.\mathrm{Na}_{2} \mathrm{SeO}_{3} \cdot 5 \mathrm{H}_{2} \mathrm{O}\right)$. 
Table 2. Effects of emulsifier and multi-enzyme on growth performance in broiler chickens ${ }^{1}$

\begin{tabular}{|c|c|c|c|c|c|c|}
\hline Items & $\mathrm{NC}$ & $\mathrm{PC}$ & $\mathrm{P} 1$ & $\mathrm{P} 2$ & $\mathrm{P} 3$ & $\mathrm{SE}^{2}$ \\
\hline \multicolumn{7}{|c|}{ Starter phase (d0to d21) } \\
\hline BWG, $\mathrm{g}$ & $856^{\mathrm{b}}$ & $956^{\mathrm{a}}$ & $977^{\mathrm{a}}$ & $927^{\mathrm{ab}}$ & $919^{\mathrm{ab}}$ & 29 \\
\hline FI, g & 1,441 & 1,494 & 1,501 & 1,430 & 1,484 & 56 \\
\hline FCR & 1.683 & 1.563 & 1.536 & 1.543 & 1.615 & 0.10 \\
\hline \multicolumn{7}{|c|}{ Grower phase (d22 to d35) } \\
\hline BWG, g & 980 & 882 & 853 & 884 & 950 & 50 \\
\hline FI, g & $1,722^{\mathrm{ab}}$ & $1,624^{\mathrm{b}}$ & $1,673^{\mathrm{ab}}$ & $1,660^{\mathrm{ab}}$ & $1,812^{\mathrm{a}}$ & 52 \\
\hline FCR & 1.757 & 1.841 & 1.961 & 1.877 & 1.907 & 0.09 \\
\hline \multicolumn{7}{|c|}{ Overall the experiment ( $\mathrm{d} 0$ to $\mathrm{d} 35$ ) } \\
\hline BWG, g & 1,837 & 1,839 & 1,831 & 1,811 & 1,869 & 50 \\
\hline FI, g & 3,163 & 3,118 & 3,174 & 3,090 & 3,296 & 67 \\
\hline FCR & 1.722 & 1.695 & 1.733 & 1.706 & 1.763 & 0.04 \\
\hline
\end{tabular}

${ }^{1}$ Abbreviation: $\mathrm{NC}$ [low energy diet, $\mathrm{ME}=3000$ (1 to $\left.21 \mathrm{~d}\right)$ and $3100 \mathrm{kcal} / \mathrm{kg}(22$ to $35 \mathrm{~d})$ ]; PC [high energy diet, $\mathrm{ME}=3150(1$ to $21 \mathrm{~d})$ and $3250 \mathrm{kcal} / \mathrm{kg}(22$ to $35 \mathrm{~d})$ )]; P1 ( $\mathrm{NC}+0.1 \%$ multi-enzyme); $\mathrm{P} 2$ ( $\mathrm{NC}+0.05 \%$ emulsifier); $\mathrm{P} 3(\mathrm{NC}+0.1 \%$ multi-enzyme $+0.05 \%$ emulsifier.

${ }^{2}$ Standard error.

${ }^{a, b}$ Means in the same row with different superscripts differ $(\mathrm{P}<0.05)$.

Table 3. Effects of emulsifier and multi-enzyme on blood profiles in broiler chickens on d $35^{1}$

\begin{tabular}{llllllc}
\hline Items & $\mathrm{NC}$ & $\mathrm{PC}$ & $\mathrm{P} 1$ & $\mathrm{P} 2$ & $\mathrm{P} 3$ & $\mathrm{SE}^{2}$ \\
\hline $\mathrm{WBC}, 10^{3} / \mathrm{ul}$ & 409 & 393 & 434 & 407 & 412 & 23.1 \\
$\mathrm{RBC}, 10^{6} / \mathrm{ul}$ & 2.24 & 2.33 & 2.30 & 2.24 & 2.25 & 0.07 \\
Glucose, $\mathrm{mg} / \mathrm{dl}$ & 245 & 272 & 248 & 251 & 251 & 14.7 \\
Triglyceride, $\mathrm{mg} / \mathrm{dl}$ & $58.8^{\mathrm{c}}$ & $107.8^{\mathrm{a}}$ & $101.5^{\mathrm{a}}$ & $77.5^{\mathrm{bc}}$ & $87.8^{\mathrm{ab}}$ & 6.89 \\
\hline
\end{tabular}

${ }^{1}$ Abbreviation: $\mathrm{NC}$ [low energy diet, $\mathrm{ME}=3000(1$ to $21 \mathrm{~d})$ and $3100 \mathrm{kcal} / \mathrm{kg}$ (22 to $\left.35 \mathrm{~d}\right)$ ]; $\mathrm{PC}$ [high energy diet, $\mathrm{ME}=3150(1$ to $21 \mathrm{~d})$ and $3250 \mathrm{kcal} / \mathrm{kg}(22$ to $35 \mathrm{~d})$ )]; $\mathrm{P} 1$ ( $\mathrm{NC}+0.1 \%$ multi-enzyme); $\mathrm{P} 2$ ( $\mathrm{NC}+0.05 \%$ emulsifier); $\mathrm{P} 3$ ( $\mathrm{NC}+0.1 \%$ multi-enzyme $+0.05 \%$ emulsifier. ${ }^{2}$ Standard error.

${ }^{a, b, c}$ Means in the same row with different superscripts differ $(\mathrm{P}<0.05)$.

Table 4. Effects of emulsifier and multi-enzyme on the relative organ weightof broiler chickens ${ }^{1}$

\begin{tabular}{lllllll}
\hline Items, \% & $\mathrm{NC}$ & $\mathrm{PC}$ & $\mathrm{P} 1$ & $\mathrm{P} 2$ & $\mathrm{P} 3$ & $\mathrm{SE}^{2}$ \\
\hline Liver & 2.38 & 2.24 & 2.10 & 2.47 & 1.76 & 0.22 \\
Spleen & $0.153^{\mathrm{ab}}$ & $0.206^{\mathrm{a}}$ & $0.102^{\mathrm{ab}}$ & $0.136^{\mathrm{ab}}$ & $0.079^{\mathrm{b}}$ & 0.33 \\
Bursa of Fabricius & $0.168^{\mathrm{ab}}$ & $0.142^{\mathrm{b}}$ & $0.143^{\mathrm{b}}$ & $0.153^{\mathrm{b}}$ & $0.285^{\mathrm{a}}$ & 0.04 \\
Breast meat & 15.88 & 15.92 & 15.30 & 15.00 & 16.74 & 0.98 \\
Abdominal fat & 1.50 & 2.20 & 2.34 & 1.84 & 1.62 & 0.35 \\
Gizzard & 1.56 & 1.61 & 1.44 & 1.38 & 1.44 & 0.13 \\
\hline
\end{tabular}

${ }^{1}$ Abbreviation: $\mathrm{NC}$ [low energy diet, $\mathrm{ME}=3000$ (1 to $\left.21 \mathrm{~d}\right)$ and $3100 \mathrm{kcal} / \mathrm{kg}$ (22 to $\left.35 \mathrm{~d}\right)$ ]; PC [high energy diet, $\mathrm{ME}=3150(1$ to $21 \mathrm{~d})$ and $3250 \mathrm{kcal} / \mathrm{kg}(22$ to $35 \mathrm{~d}))]$; P1 ( $\mathrm{NC}+0.1 \%$ multi-enzyme); $\mathrm{P} 2$ ( $\mathrm{NC}+0.05 \%$ emulsifier); P3 ( $\mathrm{NC}+0.1 \%$ multi-enzyme $+0.05 \%$ emulsifier.

${ }^{2}$ Standard error.

${ }^{a, b}$ Means in the same row with different superscripts $\operatorname{differ}(\mathrm{P}<0.05)$. 


\section{Discussion}

The results of this study indicated that the low energy density diet $(150 \mathrm{kcal} / \mathrm{kg} \mathrm{ME}$ lower) as a result of addition $6 \%$ rice rye and lower fat addition (tallow $3.0 \%$ vs. 5.5\% soybean oil) can reduce ADG from d 1 to 21 and increase ADFI from d 21 to 35. In general, the lower energy (ME) level can result in a depression of growth performance. Broilers had the ability to regulate feed intake based on the energy levels of the diet, however this effect was limited during the first week of age, especially if feed the mash feed (Jones \& Wiseman, 1985; Scott et al., 2002). The reason may be mainly attributed to the capacity limitation of the gastro-intestine of chicks.

Soybean meal contains $\alpha$-1,6-galactosidic oligosaccharides (Wang et al., 2005). These $\alpha$-galactosides have been implicated in reducing energy utilization, fiber digestion, and feed retention in soybean meal fed chickens (Coon et al., 1990). Feed enzymes have been added to poultry feed mainly to improve energy utilization in diet with high soluble non-starch-polysaccharides levels (Yu et al., 2007). The supplemented enzyme breaks the polymeric chains of the non-starch polysaccharides into smaller units thus improving the nutritive value of the feed ingredient (Smits \& Annison, 1996; Kwon et al., 2003).

Sodium stearoyl-2-lactylate (SSL) is a useful emulsifier with a very high hydrophilic-lipophilic balance in the manufacture of baked goods for many reasons and is therefore an excellent emulsifier for fat-in-water emulsions. The high emulsifying efficiency of SSL is based on its amphiphilic nature consisting of a hydrophilic charged head and long hydrophobic hydrocarbon tail.SudiptoHalda and T. K. Ghosh (2010) reported that reduction in dietary energy content may result in significant improvement in feed conversion by lowering the feed intake under the influence of nutritional emulsifiers. These improvements in FCR indicate the nutritional emulsifiers compensate for an energy reduction in broiler diets without reducing growth parameters. Jones et al. (1992) concluded that addition of emulsifiers increased digestibility of nutrients but had minimal effect on growth performance in weanling pigs.

Previous researches showed that the effects of mannanase and galactosidase enzymes on broiler performance had an inconsistent response. Whereas Jackson et al. (2003, 2004) and Daskiran et al. (2004) reported beneficial effects on BWG and FCR during starter and grower phases of growth from 80 or 110 unit/g $\beta$-mannanase supplementation. Similarly, Kidd et al. (2001) fed broilers corn and soybean meal based diets with or without an $\alpha$-galactosidase (112 $\mathrm{g} /$ ton) enzyme. They noted improved feed conversion and livability from $\alpha$-galactosidase supplementation in broilers. Wang et al. (2005) and Ao et al. (2009) also reported that growth performance was improved as a result of $250 \mathrm{mg} / \mathrm{kg}$ galactosidase supplementation with 90.2 unit/g enzyme activity or $0.1 \%$ galactosidase supplementation with 1724 unit/kg enzyme activity. On the other hand, Torki and Chengeni (2007) reported no improvement in broiler performance by adding more than $165 \times 10^{6}$ unit $/ \mathrm{kg} \beta$-mannanase into corn-soybean meal based diets. In addition, Irish et al. (1995) reported no improvement on performance in broilers by adding $0.20 \mathrm{~g} / \mathrm{kg} \alpha$-galactosidase to a corn-soybean meal.

In our experiment, Supplementation of multi-enzyme complex and/or emulsifier (SSL) to low ME diet can increase ADG to the same levels with high ME level diet. This result indicated that multi-enzyme complex can increase the energy utilization in low energy corn-soybean basal diet. Similarly, Zhou et al. (2009) reported that multi-enzyme (Xylanase, $\alpha$-amylase and protease) supplementation enhanced the ME value of diet, and improve the ADG of broilers. By preventing the formation of viscous digesta, exogenous enzymes can improve energy utilization in diet with high soluble non-starch-polysaccharides levels, such as wheat and rye (Yu et al., 2007; Zhou et al., 2009; Ao et al., 2009). Moreover, the addition of xylanase and $\beta$-glucanase can reduce the degree of bile acid deconjugation, which may also benefit the fat utilization and improve the growth performance in low density diet (Mathlouthi et al., 2002).

Multi-enzyme provided $\beta$-1,4-mannanase, xylanase, $\beta$-glucanase, and $\alpha$-1,6-galactosidase (Wang et al., 2009; Ao et al., 2011). Despite the presence of these enzymes, no significant improvements though energy in the basal diet of P1 and P2 treatments was lower compared with PC treatment, there was no difference on growth performance, blood profile, and relative organ weight in PC, P1, and P2 treatments. It indicated that SSL increased the energy utilization, so growth performance, blood profile, and relative organ weight of broiler chickens in PC, P1, and P2 treatments reached the same level. Triglyceride in P2 treatment decreased significantly, and it meant that SSL broke down the triglyceride to energy use.Wieland et al. (1993) also showed that the effectiveness of different emulsifiers in increasing the absorption of medium-chain triglycerides varied. From the difference between P1 and P2 treatment, we knew that SSL would break down more triglyceride if the energy of basal diet was lower. Praharaj et al. (1997) reported that the developments of bursa of Fabricius and spleen in broiler chicks were not influenced by dietary energy levels $(2,500,2,600$ and 2,800 $\mathrm{kcal} / \mathrm{kg}$ of ME) from d 1 to 42 . In our study, difference on bursa of Fabriciuswas observed between PC and P3 treatment. There was no difference between $\mathrm{NC}$ and $\mathrm{P} 3$ treatment, so the difference between PC and P3 was from enzymes and emulsifier.Because no difference on bursa of Fabricius wasdetected in PC, P1 and P2 treatment, we could conclude that enzymes 
increased the relative weight of bursa of Fabricius. It was good for immunity of broiler chickens when multi-enzyme was added into the diet.

Although no difference was observed among treatments during the overall period, we found significant difference on BWG in NC, PC and P1 treatments from d 0 to 21. In conclusion, the results of this study indicate that emulsifier and multi-enzyme in low-density diets can partially improve growth performance, triglyceride, and relative organ weight in broiler chickens, which can counterpart the negative effects caused by the decreased nutrient concentration.

\section{Acknowledgment}

The authors would like to acknowledge the financial assistance (No. PJ0081212012 of Bio-Green 21 program, 109155-03-3-HD120 of Agriculture and Forestry) provided by the Rural Development Administration and Ministry for Food, Agriculture, Forestry \& Fisheries, Republicof Korea. Also, this study was supported by the grant from Institute of Bio-Science and Technology (IBST) at Dankook University.

\section{References}

Ao, T., Cantor, H., Pescatore, A. J., Ford, M. J., Pierce, J. L., \& Dawson, K. A. (2009). Effect of enzyme supplementation and acidification of diets on nutrient digestibility and growth performance of broiler chicks. Poul. Sci., 88, 111-117. http://dx.doi.org/10.3382/ps.2008-00191

Ao, X., Zhou, T. Z., Meng, Q. W., Lee, J. H., Jang, H. D., Cho, J. H., \& Kim, I. H. (2011). Effects of a carbohydrase cocktail supplementation on the growth performance, nutrient digestibility, blood profiles and meat quality in finishing pigs fed palm kernel meal. Livest. Sci., 137, 238-243.

AOAC. (2003). Official Methods of Analysis. 17th ed. Association of Official Analytical Chemists, Arlington, V. A.

Armero, E., \& Collar, C. (1998). Crumb firming kinetics of wheat breads with anti- staling additives. J. Cereal. Sci., 28, 165-174. http://dx.doi.org/10.1006/jcrs.1998.0190

Augur, V., Rollman, H. S., \& Deuel, Jr. H. J. (1947). The effect of crude lecithin on the coefficient of digestibility and the rate of absorption of fat. J. Nut., 33, 177.

Daskiran, M., Teeter, R. G., Fodge, D., \& Hsiao, H. Y. (2004). An evaluation of endo- $\beta$-D-mannanase (Hemicell) effects on broiler performance and energy use in diets varying in $\beta$-mannan content. Poul. Sci., 83, 662-668.

Coon, C. N., Leske, K. L., Akavanichan, O., \& Cheng, T. K. (1990). Effect of oligosaccharide-free soybean meal on true metabolizable energy and fiber digestion in adult roosters. Poul. Sci., 69, 787-793. http://dx.doi.org/10.3382/ps.0690787

Ghazi, S., Rooke, J. A., Galbrith, H., \& Morgan, A. (1997). Effect of adding protease and alpha-galactosidase enzymes to soybean meal on nitrogen retention and true metabolizable energy in broilers. B. Poul. Sci., 38, S25-S45.

Ghazi, S., Rooke, J. A., \& Galbraith, H. (2003).Improvements in the nutritive value of soybean meal by protease and $\alpha$-galactosidase treatment in broiler cockerels and broiler chicks. B. Poul, Sci., 44, 410-418. http://dx.doi.org/10.1080/00071660310001598283

Gitzelmann, R., \& Auricchio, S. (1965). The handling of soy alpha-galactosidase by a normal and galactosemic child. Pediatrics., 36, 231-232.

Gómez, M., Delreal, S., Rosell, C. M., Ronda, F., Blanco, F., Blanco, C. A., \& Caballero, P. A. (2004). Functionality of different emulsifier on the growth of breadmaking and wheat bread quality. Eu. F. Res. Tech., 219, 145-150.

Irish, G. G., Barbour, W., Classen, H. L., Tyler, R. T., \& Bedford, M. R. (1995). Removal of the $\alpha$-galactosides of sucrose from soybean meal using either ethanol extraction or exogenous $\alpha$-galactosidase and broiler performance. Poul. Sci., 74, 1484-1494. http://dx.doi.org/10.3382/ps.0741484

Jackson, M. E., Anderson, D. M., Hsiao, H. Y., Mathis, G. F., \& Fodge, D. W. (2003). Beneficial effect of $\beta$-mannanase feed enzyme on performance of chicks challenged with Eimerla sp. and Clostirdiumperfringens. Avian Diseases., 47, 759-763. http://dx.doi.org/10.1637/7024

Jackson, M. E., Geronian, K., Knox, A., Mcnab, J., \& Mccartney, E. (2004). A dose response study with the feed enzyme $\beta$-mannanase in broilers provided with corn-soybean meal based diets in the absence of antibiotic growth promoters. Poul. Sci., 83, 1992-1996. 
Jones, R. L., \& Wiseman, J. (1985). Effect of nutrition on broiler carcass compostion: influence of dietary energy content in the starter and finisher phases. B. Poul. Sci., 26, 381-388. http://dx.doi.org/10.1080/00071668508416826

Kelly, P. M., Oldfield, J., \& O'kennedt, B. T. (1999). The thermostability of spray dried imitation coffee whiteners. Int. J. Dairy. Tech., 52, 107-113. http://dx.doi.org/10.1111/j.1471-0307.1999.tb02082.x

Kidd, M. T., Morgan, Jr. G. W., Price, C. J., Welch, P. A., \& Fontana, A. (2011a). Enzyme supplementation to corn and soybean meal diets for broilers. J. Appl.Poul. Res., 10, 65-70.

Kidd, M. T., Morgan, Jr., G. W., Zumwalt, C. D., Price, C. J., Welch, P. A., Brinkhaus, F. L., \& Fontana, E. A. (2001b). $\alpha$-Galactosidase enzyme supplementation to corn and soybean meal broiler diets. J. Appl.Poul. Res., 10, 186-193.

Kim, S. W., Knabe, D. A., Hong, K. J., \& Easter, R. A. (2003).Use of carbohydrases in corn-soybean meal-based nursery diets. J. Anim. Sci., 81, 2496-2504.

Knap, I. H., Ohmann, A., \& Dale, N. (1996). Improved bioavailability of energy and growth performance from adding alpha-galactosidase (from Aspergillus sp.) to soybean meal-based diets. (pp. 153-156). In Proc. Aust. Poult. Sci. Symp. 8, Sydney, Australia.

Kussaibati, R., Guillaume, J., \& Leclercq, B. (1982). The effects of age, dietary fat and bile salts and feeding rate on apparent and true metabolizable energy value in the chick. B.Poul. Sci., 23, 393-403. http://dx.doi.org/10.1080/00071688208447973

Kwon, O. S., Kim, I. H., Lee, S. H., Hong, J. W., Kim, J. H., Moon, T. H., \& Lee, J. H. (2003). Effect of dietary $\alpha-1,6$-galactosidase and $\beta-1,4$-mannanase on growth performance and nutrient digestibility in nursery and growing pigs. Kor. J. Anim. Sci. Technol., 45, 211-218.

Manhar, R. S., \& Rao, P. H. (1999). Effect of emulsifiers, fat levels and type on the rheological characteristics of biscuit dough and quality of biscuits. J. Sci. Food. Agri., 79, 1223-1231. http://dx.doi.org/10.1002/(SICI)1097-0010(19990715)79:10<1223::AID-JSFA346>3.0.CO;2-W

NRC. (1994). Nutrient Requirements of Domestic Animals. Nutrient Requirements of Poultry. 9th rev. ed. Natl. Acad. Sci., Washington, DC.

Polin, D. (1980). Increased absorption of tallow with lecithin. Poul.Sci., 59, 1852 (Abstr.).

Praharaj, N. K., Dunnington, E. A., Gross, W. B., \& Siegel, P. B. (1997). Dietary effects on immune response of last-growing chicks to inoculation of sheep erythrocytes and Escherichia coli. Poul. Sci., 76, 244-247.

Ray, S., Pubols, M. H., \& Mcginnis, J. (1982). The effect of a purified guar degrading enzyme on chick growth. Poul. Sci., 61, 488-494. http://dx.doi.org/10.3382/ps.0610488

SAS. (1996). SAS user's guide. Release 6.12 Editions. SAS Institute. Inc Cary NC. USA.

Scott, T. A. (2002). Evaluation of lighting programs, diet density, and short-term use of mash as compared to crumbled starter to reduce incidence of sudden death syndrome in broiler chicks to 35 days of age. Can. J. Anim. Sci., 82, 375-383. http://dx.doi.org/10.4141/A01-067

Smis, C. H. M., \& Annison, G. (1996). Non-starch plant polysaccharides in broiler nutrition-towords a physiologically valid approach to their determination. World's Poul. Sci. J., 52, 203-221. http://dx.doi.org/10.1079/WPS19960016

Studipto, H., \& Ghosh, T. K. (2010). Nutritional emulsifiers sustains performance of broiler fed a low-energy diet $\quad-a$ new approach to alleviate tropical heat stress. http://en.engormix.com/MA-poultry-industry/health/articles/nutritional-emulsifiers-sustains-performance-t1 505/p0.htm.

Torki, M., \& Chengni, A. (2007). Evaluation of dietary replacement of soybean meal by canola meal supplemented by $\beta$-mannanase (Hemicell) on performance of broiler chicks. 16th European Symposium on Poultry Nutrition, Strasbourg, France. 637-640.

Waldruop, P. W., Fritts, C. A., Keen, C. A., \& Yan, F. (2005). The effect of $\alpha$-galactosidase enzyme with and without Avizyme 1502 on performance of broilers fed diets based on corn and soybean meal. Int. J.Poul.Res., 4, 920-937.

Wang, C. L., Lu, W. Q., Li, D. F., \& Xing, J. J. (2005).Effects of alpha-galactosidasesupplementation to corn-soybean meal diets on nutrient utilization, performance, serum indices and organ weight in broilers. 
Asian-Aust. J. Anim. Sci.., 18, 1761-1768.

Wang, J. P., Hong, S. M., Yan, L., Yoo, J. S., Lee, J. H., Jang, H. D., Kim, H. J., \& Kim, I. H. (2009). Effects of single or carbohydrases cocktail in low-nutrient- densitydiets on growth performance, nutrient digestibility, blood characteristics, and carcass traits in growing-finishing pigs. Livest. Sci., 126, 215-220.

Wieland, T. M., Lin, X., \& Odle, J. (1993). Utilization of medium-chain triglycerides by neonatal pigs: Effects of emulsification and dose delivered. J. Anim. Sci., 71, 1863-1868.

Yu, B., Wu, S. T., Liu, C. C., Gauthier, R., \& Chiou, P. W. S. (2007). Effect of enzyme inclusion in a maize-soybean diet on broiler performance. Anim. Feed Sci. Tech., 134, $283-294$. http://dx.doi.org/10.1016/j.anifeedsci.2006.09.017

Zhou, Y., Jiang, Z., Lv, D., \& Wang, T. (2009). Improved energy-utilizing efficiency by enzyme preparation supplement in broiler diets with different metabolizable energy levels. Poul. Sci., 88, $316-322$. http://dx.doi.org/10.3382/ps.2008-00231 